\title{
Should general practitioners be informed of patients' convictions for drug offences?
}

\author{
We received this letter from Dr R G Neville, lecturer in general \\ practice, and asked four people to respond to it.
}

The problems facing society in coping with controlled drug addiction are considerable. The courts, police, lawyers, social workers, general practitioners, and hospital doctors are faced with similar difficulties when managing clients or patients known to be or suspected of being addicted to heroin. A legal framework already exists whereby doctors must notify the Home Office's drugs branch of any person they suspect or have reason to suspect is addicted to a controlled drug.' Interest has recently been focused on whether GPs should be informed of convictions for drunk driving among their patients.

Clearly, the fact that a patient has been convicted on drugs charges is important to GPs. Information relating to convictions is, of course, available from court records and at times reported in the local press. If, however, GPs were notified formally by the courts of such convictions this would be of great value in recognising and managing patients with controlled drug addiction. On receipt of such information GPs would then be in a position to notify the Home Office and have the patient's name entered on the misuse of drugs register.

Should such a notification system be introduced? An intrusion on civil liberty this may be, but surely that is a small price to pay for a means of helping fight Britain's drug problem.-R G NEviLLE

\section{A general practitioner with an interest in ethics}

There was no doubt about my gut reaction on reading this proposal: a distinct "ugh response," in Ian Kennedy's immortal phrase. But gut responses are not necessarily morally reliable responses and need analysis. The main moral issues in this case seem to concern harm and benefit to patients and society. Dr Neville implicitly suggests that his proposal would primarily protect British society in its battle against "Britain's drug problem," though possibly he indicates too that the convicted patients and their GPs would also benefit. Quite apart from the civil rights issues mentioned by Dr Neville, I am sceptical of the benefit to society of the change he proposes. If the proposal is that better track may be kept of people with drug convictions if they are notified to the Home Office then the courts themselves could make such notifications directly. If the objective is to "have the patient's name entered on the misuse of drugs register" that too could in principle be done directly by the convicting court. What additional advantage, sufficient to outweigh what seems to me the disadvantage of making doctors seem like ancillary law enforcement officers, might there be in requiring such notifications to be made by the convicted person's GP?

It might be argued that the GP would then be able to treat the person for his or her drug problem. But either the person wants to be treated for a drug problem or he does not. If treatment is wanted then the person may under existing arrangements approach a doctor, whether in general practice or specialised drug practice, and there is nothing to stop the court reminding drug offenders of this. If treatment is not wanted then it might be argued that it should at least be offered to those convicted of drug offences, and perhaps even be imposed on them. Even if one or both of these claims are accepted there still seems no need for them to be achieved by routinely notifying GPs of their patients' drug convictions as courts could be empowered to carry them out directly. Thus the courts could require medical assessment of those convicted of drug offences and then, if appropriate, judicially suggest treatment, perhaps offer reduction in sentence if treatment is accepted, or, in rare cases, order treatment.

The primary moral objective of doctors is to help medically those patients who need and want such help. Although this self imposed moral obligation is not absolute and may sometimes be overridden by a doctor's obligations to society, each time it is overridden the special trust that is so necessary to achieve the best medical care is undermined. Thus it seems undesirable to institute a proposal such as Dr Neville's that would unnecessarily impose additional threats to the doctor-patient relationship while offering minimal or no benefit to either patients or society. Furthermore, even if such benefits as might arguably be attained by Dr Neville's proposal were desired they could be equally well achieved by direct action on the part of the courts without any need to inform GPs routinely of their patients' convictions for drug offences.-RAANAN GILLON

\section{Secretary of the British Medical Association}

Clearly, important advantages would be gained from notifying the GP of convictions associated with the misuse of alcohol and other drugs. It has long been recognised that conviction of drinkdriving offences is a remarkably consistent characteristic event and occurs early in the history of alcoholism. Attention has recently been drawn to the extent to which the association of alcohol with disease may escape recognition in patients in hospital. A record of conviction in the notes would certainly alert the clinician to a possibly important factor in diagnosis and treatment. More recently, recognition of the close association of cocaine misuse with criminality suggests that notification of a conviction would alert the profession to a problem that has spread rapidly in North America and has made its appearance here.

There must, however, be cast iron reasons for disclosing such information to third parties without consent. A permanent record of such convictions in the clinical notes could be unfavourable when a report is sought from the medical attendant for purposes of insurance, mortgages, employment, etc.

Unfortunateiy, little is known about the characteristics of drinkdriving offenders in this country. Surveys from other countries, where requirements for conviction may well be different, suggest that about half the offenders do not require any form of treatment. There might be a case for notifying the "high risk" offender in this country - that is, those with two convictions within a ten year period with levels of alcohol in excess of $200 \mathrm{mg} / 100 \mathrm{ml}$. Such cases, however, are reported by the courts to the medical department of the Driver Vehicle Licensing Centre in Swansea, which will probably contact the offender's own doctor (with consent) about applications for reinstatement of the licence.

A further point is that those convicted of offences of the misuse of other drugs, even though registered with an NHS doctor, may have no regular medical attendant.-JOHN HAVARD 


\section{A general practitioner}

Any sound that Winston made above the level of a low whisper would be picked up by the telescreen. There was, of course, no way of knowing whether you were being watched at any given moment. It was even conceivable that the "Thought Police" watched everybody all the time.

The idea that all information is valuable is attractive but dangerous. The suggested proposal would set two precedents: firstly, the courts' proactive distribution of information about citizens outside the legal system and, secondly, the doctors' acceptance of unsolicited information. This raises the obvious question of where to draw the line. If the courts may pass such information to doctors, why not to others? If the doctors are to receive unsolicited information from the courts, why not from other sources too?

Whatever the intentions of the proposal itself, it may be difficult for doctors not to be seen by many to have become a part of the legal system or even to have become agents of social control. The greatest argument in favour of acquiring the information in this way might be that venesection could be performed with appropriate precautions to minimise the risks of contracting hepatitis $\mathrm{B}$ and the acquired immune deficiency syndrome. The doctor's rapport with his patients, however, may be more important than this information. Some doctors choose not to look after drug addicts and might ask a person to leave their list. If there is a good relationship between the GP and the person concerned he may have told the doctor of his drug problem. If he has chosen not to do so the knowledge could be difficult to handle and could sour the relationship. Nevertheless, there could be an occasion when the knowledge was valuable.

My local clerk to the court tells me that information from court records is not available to the public, except by listening to the court proceedings. Presiding justices could recommend offenders to tell their doctors of their addiction if the offender thought it might help. For the purposes of the misuse of drugs register surely the courts could notify the Home Office directly.-PETER TOMSON

\section{A chief constable}

Dr Neville poses a pertinent yet sensitive question. Although there are considerable practical difficulties, in principle I would answer yes to his question: GPs should be informed of their patients' convictions for drug offences.

Much is heard about the alleged growth in drug addiction and dependency. Certainly, there is evidence that criminal activity in the importation and distribution of controlled substances is increasing. Those who deal in drugs usually attain returns that far exceed those available from, for example, burglary or robbery. Demand does appear to be increasing, and detection, whether by customs or police, is becoming more difficult. I say there is an apparent growth because although we can see the number of drug offenders from annual statistics, we can only speculate on the actual level of abuse. An increase in the rate of detection may reflect more activity by the enforcement agency or it may, as claimed, represent a disturbing rise in criminal activity.

Police, the customs and excise service, and the criminal justice system cannot stand alone. There is a need for a corporate approach to address all aspects of this disturbing social threat. Enforcement, education, treatment, and rehabilitation are not mutually exclusive. All who are engaged in these pursuits must collaborate and coordinate their activities. A climate needs to be created similar to that which has developed in the identification of child abuse. Trust and confidence must be achieved among professional people to meet the serious challenge posed by drug abuse. The point I make is that those professional bodies and subjects concerned must cooperate in identifying the nature of the problem and, particularly, the source of supply. It is only then that we may assess the task at hand and deploy our expensive yet scarce resources effectively and efficiently.

In principle, therefore, I agree that GPs should be aware of their patients who are convicted of drug offences. It seems eminently sensible when it is acknowledged that doctors have a duty to advise the Home Office of those whom they believe to be addicted. Notification of convictions and the corporate approach described would be seen by some as a further erosion of civil liberties. Such concern cannot be ignored. On occasions, however, the welfare of society at large must predominate. The objective of attacking the roots of drug related crime by tracing and eliminating the source demands positive action.

There are, nevertheless, practical obstacles inherent in $\mathrm{Dr}$ Neville's proposal. Before notification could take place a person convicted of a drug offence might be required to disclose the identity of his GP. Would it be an offence not to disclose such information to a court and, if so, what would be the sanction? Equally, not everyone would be registered with a GP.

In 1984,22882 people were convicted of offences relating to drugs, 15185 offences relating to cannabis alone. If the onus of disclosure was not placed on the offender notification would have to be made by the courts to the National Health Service, which, in turn, would be responsible for tracing and advising the relevant GP. Such procedures would not be without administrative burdens for both the judicial and health authorities, yet the ultimate aim of the recognition and management of human tragedy requires that $\mathrm{Dr}$ Neville's proposal be seriously considered. - J E OvER

\section{References}

1 Department of Health and Social Security. The misuse of drugs (notification of and supply to addicts) regulations 1973. London: HMSO, 1973.

2 Dunbar JA, Ogston SA, Ritchie A, Devgun MS, Haggart J, Martin PT. Are problem drinkers dangerous drivers? An investigation of arrest for drinking and driving, serum $\gamma$ glutamyltranspeptidase activities, blood alcohol concentrations, and road traffic accidents: the Tayside Safe Driving Project. Br Med f 1985;290:287-30.

\section{Authors}

R G NEVILLE, MRCGP, DOBSTRCOG, is lecturer in general practice, Department of General Practice, University of Dundee, West Gate Health Centre, Dundee DD2 4AD.

RAANAN GILLON, MB, MRCP, is director of Imperial College Health Service, Imperial College of Science and Technology, London SW7 INA, and editor, Foumal of Medical Ethics.

JoHN HAVARD, MD, MB, is secretary of the British Medical Association, London WC1H 9JR.

PETER TOMSON, FRCGP, DOBSTRCOG, is a general practitioner, The Group Surgery, Vine House, Abbots Langley, Hertfordshire WD5 OAL.

J E OvER, QPM, CPM, is chief constable, Gwent Constabulary Headquarters, Croesyceiliog, Cwmbran, Gwent NP44 2XJ.

\section{WORDS}

SCALPEL. The small surgical knife, known as a scalpel, has been in use at least since Graeco-Roman times. The word is almost unchanged from the Latin scalpellum, the suffix -ellum indicating the diminutive of scalprum, a sharp cutting instrument as used by farmers, shoemakers, and sculptors; evidently a larger cruder implement. The verb scalpo, to cut, scrape, engrave, merges with sculpo, which has much the same meaning but includes "to form by carving," whence "sculptor," a word that has entered the English language unchanged. Sadly, two useful words have been lost on the way-scalptorium and auriscalpium. The scalptorium was an instrument in the form of a hand for scratching oneself. I am the grateful recipient of one of these backscratchers; it is made of an African hardwood and its distal extremity is shaped into a small hand whose partially flexed fingers are nicely adapted to reach that not too accessible interscapular area. The auriscalpium, another toiletry article, was an earpick, so useful for extracting cerumen and for obtaining relief from itching. The handy modern alternative for personal use at home and work seems to be the wire paperclip.-B J FREEDMAN. 